\title{
「レーザー駆動中性子源の学術・産業応用に向けた展望」特集号によせて
}

\author{
三間 图興 ${ }^{1}$, 福嶋 喜章 ${ }^{2}$ \\ 1光産業創成大学院大学 ( ⿳亠丷厂 043-1202 静岡県浜松市西区呉松町1955-1) \\ 2公益財団法人 特殊材料研究所 ( $7982-0252$ 仙台市太白区茂庭台2-6-8)
}

\section{Preface to Special Issue on Prospects for Academic and Industrial Applications of Laser-driven Neutron Sources}

\author{
Kunioki MIMA $^{1}$ and Yoshiaki FUKUSHIMA ${ }^{2}$
}

${ }^{1}$ The Graduate School for the Creation of New Photonics Industries, 1955-1 Kurematsu, Nishi-ku, Hamamatsu, Shizuoka $043-1202$
${ }^{2}$ Advanced Institute of Materials Science, 2-6-8 Moniwadai Taihaku-ku, Sendai, Miyagi 982-0252

(Received June 30, 2018)

\begin{abstract}
In this special issue, the present status and the prospects of applications of laser driven neutron sources are reviewed. In particular, the unique applications related to the merits of laser neutron sources, such as compactness of system size, short pulse, and small source size. As an example, the neutron resonance absorption radiography is described, which will be applied to diagnose elemental distributions in massive objectives. The useful resonance lines for this applications are shown in the figure. The contents of the following chapters are 1) Status of $R \& D$ of neutron optics and diagnostics, 2) Compact moderator design for laser neutron source, 3) Examples of academic, industrial, and medical applications of compact accelerator driven neutron sources, 4) Industrial applications in UK, and so on.
\end{abstract}

Key Words: Neutron optics, Security of infrastructure, Neutron resonance absorption, Radiation shielding, Neutron imaging, Compact moderator

\section{1. 本特集号によせて}

中性子ビームは光, 電子, イオンと並び“第4の量子 ビーム”と考えられる。 その高い透過性と低エネルギー で原子核と強く相互作用するのが特徵である。軽元素と の相互作用と重元素との相互作用が同程度であり，金属 内軽元素物質の検出やイメージングに有効であること で，荷電粒子線やX線の利用にくらべ，ユニークな応用 が可能である.

従来，原子炉中性子源の利用が中心であったが，その 後, J-PARC等大型の加速器中性子源が世界各国で稼働 し, 中性子科学が進歩し, 学術, 科学技術, 医療, 産業 利用分野が広がった。学術分野では物性研究，生体物質 科学, 生命科学, 電磁材料, 原子核工学等へ利用が広が り, 医療応用ではBNCT癌治療, 産業・社会利用では, 橋梁等の社会インフラの健全性チェック，鉄鋼材料開 発, 自動車産業, リチウムイオン電池診断, 等への利用 が進んでいる。

レーザー中性子源は小さいソースサイズで短パルスが 特徵である。ささらに、レーザー装置本体が放射線管理の 対象外である事より, 中性子発生のための高エネルギー 粒子ビームを加速する空間が極めて小さい.すなわち,
放射線シールドのための構造物を極めて小さくできる可 能性があるのも利点である。これらの特長を生かした レーザー駆動中性子源利用の可能性を探るのが，この特 集号を企画した目的である.

例えば，橋梁やトンネル等の野外での社会インフラの 健全性チェック，自動車等の製造現場での中性子利用も

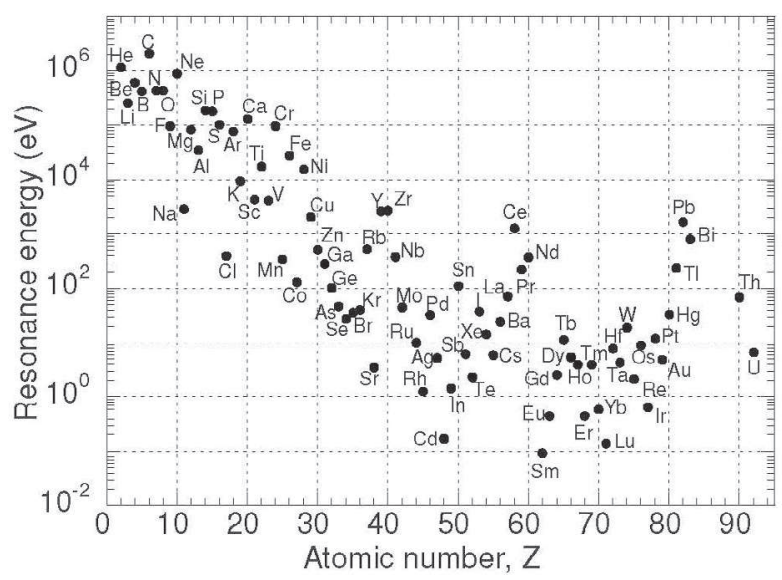

Fig. 1 Energies of neutron resonances giving the largest visibility (defined in reference 1) for each element. 
可能になると期待される. また，短パルス化が可能とい うレーザー中性子源の特長を生かした中性子計測手法と して，原子核と中性子の共鳴反応を利用して特定の元素 分布を選択的に可視化する共鳴吸収イメージング技術が 注目されている ${ }^{1,2)}$. Fig. 1 には，この手法での利用が想 定される共鳴反応のエネルギーを核種毎に示した。広い エネルギー範囲で高い分解能を得る必要があり, レー ザー中性子源の短パルス性を有効に活用できる手法とし て期待される.

本特集では，中性子計測技術開発とその基盤技術， レーザー中性子減速用モデレータの設計と中性子オプ ティクス, 中性子利用技術一学術分野への中性子利用, インフラ中性子診断を目指したコンパクト中性子源開発
の動向, 加速器駆動コンパクト中性子源の産業・医療 への利用，並びに，英国におけるLaser driven neutron source development for industrial applicationsにより, レー ザー中性子源の利用とその関連分野の技術開発につき, 現状と発展可能性を展望する。最後に，J-PARCの甲斐 氏より原子核と中性子共鳴反応を利用する計測につきコ メントいただいた事を申し添える。

\section{参考文献}

1) T. Kai, F. Maekawa, H. Oshita, H. Sato, T. Shinohara, M. Ooi, M. Harada, S. Uno, T. Otomo, T. Kamiyama, et al.: Physics Procedia 43 (2013) 111.

2）甲斐哲也：Isotope News 727 (2014） 16. 